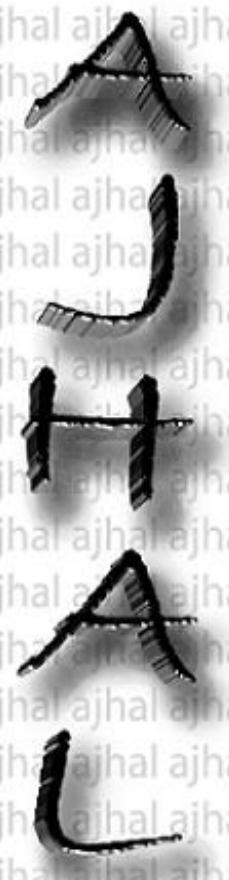

[SSN 2314-8636

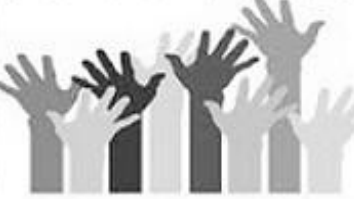

THERET5ாם 토月P工田

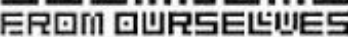
잩 HШாПП 코느ㅌㅣㅐㅛ

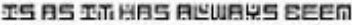
月กㅋ 트 5ㅁㄴㅃㅌㅡ

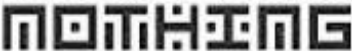

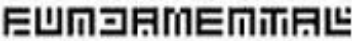

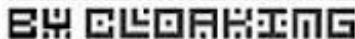
口URSE느트

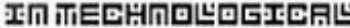
Б늠ㅁㅍㅜ Vol 3, No. 1/2016

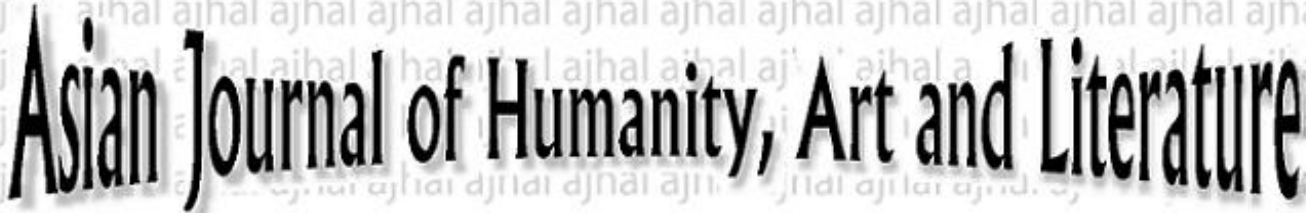




\section{Voice of Protest against Choice of Politics: A Study of Selected Texts in South African Literature}

ISSN: 2311-8636 (Print) ISSN: 2312-2021 (Online)

DOI prefix: 10.18034/ajhal

Licensed:

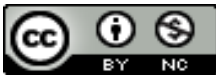

Source of Support: Nil

Conflict of Interest: None Declared

*Email for correspondence: morve_roshan@rediffmail.com

\section{Morve Roshan K.}

Center for Comparative Literature and Translation Studies, School of Language, Literature \& Culture Studies, Central University of Gujarat, Gandhinagar - 382030, Gujarat, INDIA

\section{ABSTRACT}

This paper interrogates the nature of protest literature as well as their issues and problems while addressing the discourse on apartheid South Africa underlined the politics. In this paper, I explore the connection of banned books of history with the present time. In South Africa: the numbers of the books banned, and these books never become part of a literary form. As a result, it also claims to the Censorship Act (have an authority to ban the books). This paper relates to examine the relationship between these two major research queries, which underpins as under two contexts as: (i) Protest literature and (ii) Racial discrimination. The racial discrimination needs for understanding the problems and struggle in South African. It also ignites to the fight for human rights of the people, who suffer from inequality and struggling for their identity crisis. South African novels represent the problems and concerns of people who belong to the marginal group. However, this paper focuses on South African protest literature, which demands to the end of racial discrimination, unequal educational system and segregation as divided land policy represents through the discourses. This paper has significant to demand for equality and justice through the protest literature also it demands of non-racial society as well. I come to conclude, it can be inferred in apartheid and the postapartheid government failed to give equal rights to all.

Key Words: Protest literature; Censorship Act; Apartheid; South Africa; politics; racial discrimination

\section{INTRODUCTION}

The protest literature in South Africa, which is not an individual struggle of one person, but a group of people. It is a piece of writing, which defines the perfect form of their pain and suffering. In addition, it attempts to protest, against political inequality, for both as equality and justice. It criticizes to apartheid act of racial discrimination that resulted in inequality and unjust system of rights. 'They need to demand complete revolution' (Morve, 202). It is a very comprehensive idea of control power politics. The adversity that the similar issues are always in the form of exploitation, racial power to dominate and weak constitutional law so, it is necessary to rethink of equal rights. The social consciousness is the opposite side of the conventional rules (Morve, 201). 


\section{Mohan writes:}

Protest of an individual is not confined to him alone; it is reflected in society as well. It cannot be separated from social, cultural and political circumstances. Protest-inspired values relate to real situations. Protest literature included prose that denounced the race-based oppression and promoted social equality and upward mobility in urban, black communities (Graham, and Warad 117).

The writing of South African and their problems contribute in the contextual framework of the writer in his literary work. South African literary writing proposes a model of equal rights and treatment of the society and Government. At the point of view, the South African protest of a writer to demonstrate the discriminatory law of apartheid. It not only brings anxiety as in South Africa but also fails to give rights to the citizens. The writer writes their experiences of racial discrimination and unequal treatment by the government in their narrative style. The administration acknowledged African National Congress as a legal opposition party. The writing emphasizes that the Apartheid Act brings the tension within the society; afterwards people raise their voice against this law and joint protest party like Anti-Apartheid Movement (AAM). What is the purpose of propagating the Apartheid Act in the government organization and institutional structure? It is very significant to study this question and address the aim of apartheid act, which gives rise to different types of classes and groups. The target was the continuation as a separate ethnic group of the present white population. In the long history of establishing subject, "race" has occupied categories of fixing personal and collective existences.

The meaning of Apartheid:

The South African Government's system of racial "apartheid" meaning "apartness." It was a mode used to promote "separation." Also, in South Africa for the policy initiated by the Nationalist Government after 1948. Under the same act an African people, Cape Coloured or Indian descent were forcibly removed from urban areas where they had lived for generations. Further segregation was maintained by the use of pass laws, which required non-whites carry a pass that identified them (Ashcroft, et al. 17-18).

\section{Presentation}

Noting with great apropos of this study investigates the role of apartheid history in novels associate of apartheid writer. In Africa, Apartheid Act starts in 1948 to the ends in 1994. The forceful physical separation between races by creating different residential areas for different races. Racial discrimination emerges within the society under apartheid act black, white, 'coloured' and Asian because they got a pass of civilization. In some parts of South Africa, white farmers occupied land at their own option without any regard for the needs of the African population. Essentially, in the perspective of critic's apartheid is an unconscious process of displacement of individuals also the segregation policy and separate development. In South Africa the places, where apartheid act was in practice, there were political landscapes - Cape Town, Soweto, Township, Cape Province, Natal, Gauteng, Lesotho, Johannesburg and Transvaal. All these regions struggled to protest against apartheid and raised voice against discrimination policy. In the contextual framework of apartheid leads to a crisis of identity. Jones and Jones write:

The dominating influence in South African literature, indeed, in all South African culture has been apartheid. Its stark polarities of black versus white, oppression versus liberty and poverty versus opulence, have produced a literature of protest liberty, which is limiting even in its compelling necessity (Jones, and Jones Vii).

The protest literature demands of the social justice, equality and decries this evil act. The African writers write about the racial experiences in the literary writing, but the political acts of censorship the number of books are banned. An account of the white supremacy and marginal people, who are 'black' and 'coloured' suffered for their ruling power. The 
literature has the aim to raise the voice of marginal people to aware their pain, suffer and struggle to the world. In the context of Africa I can say, Apartheid writing is a protest literature, and begin from the discriminatory rules was in the practice.

Herlitzius writes, in Africa, two pieces of literatures exist -

(i) Liberal Realist

(ii) Protest literature

The emphasis on 'non-white' authorship in the context of protest literature is seen as making a shift from liberal-realist writing. According to the sense, these are considered as two separate genres, which are contradictory. Protest literature by 'black' authors was banned by law in 1966 so that the situation of 'black' writers worsened dramatically. In 1960, the list of 'black' writers, including the name of Es'kia Mphahlele, Lewis Nkosi, Can Themba, and Nat Nakasa; they exiled from their own land - a situation referred to as the 'silencing of an entire generation of black writers,' or as Richard Rive puts it: "South African writing in English virtually became White by law" (Herlitzius 88).

In South Africa, the studies have been there on various aspects of apartheid fictions, which establishes historical as well as a critical overview of discrimination about racial segregation. The books like J. Uledi-Kamanga Brighton's Cracks in the Wall: Nadine Gordimer's Fiction and the Irony of Apartheid (2001) and Sten Pultz Moslund's Making Use of History in New South African Fiction: Historical Perspectives in Three Post-Apartheid Novels (2003). Similarly, Mongane Wally Serote's God's of Our Time, Mike Nicol's The Ibis Tapestry and Zakes Mda's Ways of Dying. Geoffrey V. Davis's Voices of Justice and Reason: Apartheid and Beyond in South African Literature (2003), which traces the development of literature in South Africa under apartheid and attempt to identify how writings are now facing the challenge of a new social order. Richard Peck's A Morbid Fascination: White Prose and Politics in Apartheid South Africa (1997), which uses a political culture of white South Africa (Killam and Kerfoo 165-77). In their novels, the protagonist represents the apartheid conflict for their unequal treatment by the society and their demands for equality in education system, race, land, and so on.

Mehta and Narang (1989) write:

If the majority of African novelists, poets and dramatist, seem eager to explore traditional African values and if the intention is to see how these values might determine literature of South Africa is wholly concerned with the themes of struggle and conflict between the white conquerors and conquered black, between white masters and black servants, between the village and the city (Mehta and Narang 41).

Fifty years later, Stephen Gray published his book Southern African Literature: An Introduction. He was aware that he was living in "divided country," where apartheid had come to determine all aspects of literary practice. The writers had been forced into exile, while in the country itself. Their works were no longer legally available, and they were banned (Eckstein 86). Racial discrimination is the essence of the writing in Africa (Morve, 210). Apartheid complex of South Africa represents in writing like Joyce Sikakane's $A$ Window on Soweto (1977) or Nelson Mandela's Long Walk to Freedom (1995). African cities like Johannesburg have long been tainted by their genesis in colonial and neocolonial exploitation and much African fiction, like Maja Mwangi's Kill Me Quick (1973) or Ayi Kwei Armah's The Beautiful Ones Are Not Yet Born (1968). South African writers with their peculiar history of 'apartheid' and the conquest, political, cultural and psychological situation, understandably adoption attitude is closer to protest. Arbitrary censorship is imposed on the creative writers. Also, many books are banned, and these writers imprisoned or some of them exiled for their writing. 'South African censorship in its systematic phase, from the coming into force of the Publications and Entertainments Act of 
1963 to the negotiation of a democratic constitution. The books were banned to achieve political or religious motivation. In Alan Paton's Cry the Beloved Country, we find the elements of propaganda novel where the evils of discrimination strongly represented' (Kam 36; Coetzee 186). Similarly, the novels that tell the story of racial discrimination, Kente Gibson's How Long, I Believe and Too Late (1974-76), melodramas attacking apartheid. Farida Karodia's novel Daughters of Twilight (1986), this is a story of 'coloured' family in South Africa relates their struggle to live normally in an abnormal world. Interweaving political, personal and moral threads in this sympathetic novel (Malhotra195). Karodia's collection of short stories, Coming Home and Other Stories (1988), shows her skill and versatility in depicting the protagonists of various ethnic groups. A Boer girl, a black teacher, a 'coloured' mother and a white employer' (Killam and Kerfoot 159). Rosemary Jolly (1995) is quite right in reminding us that smacks of apartheid, which is the term used to refer to racial segregation, which was practiced before the 1990s in South Africa. In this regard, be noted ever since the emergence of the mainly black African National Congress as the ruling Party of South Africa in 1994. The country itself had abandoned apartheid as an official policy (Talib 45). As Rive remarks: "The theme of protest literature is also the discrimination implicit in black-white relationships, and its writing is critical of white racial domination. Its literature is produced by blacks, unenfranchised non-citizens for whites who have the vote and so can effect change" (Herlitzius 81). Nadine Gordimer's novels and short stories also express the cross-racial relations and their anti-apartheid struggle. 'She captures these issues in My Son's Story (1990) with the social-political and historical essence of apartheid. The study is significant in the context of present time as it enables to perceive parallels in other projects in writing back resistance on the global map. Resistance is a component of the negotiation or protest as described by the characters Aila, Will, Sonny, Hannah and Baby. They fight against the treatment of unequal justice. The writer's voice against inequality and unjust system that had crippled the life of their people. The hardening attitude of the South African regime was the most dramatic and vicious form in 1948 when Prime Minister Malan ended the Nationalist government's racial policy.

Alex La Guma pointed out to the fact that by 1969 South African government banned some 13,000 books. The government was in the regular habit of altering posters advertising those American films that showed black and white people together. Under the existence of the regime, politically active writers and poets were exiled. One need only remembers the names of Nat Nasaka, Arthur Nortje, Dennis Brutus and Lewis Nkosi who were, among others, forced to flee their country (Yousaf X). As a white liberal Gordimer has always found herself an outsider in her country. In her The Late Bourgeois World (1966) dehumanizing institution of apartheid and its repercussions for those who will it so. The country South African writer continually comes up against phenomena resulting from apartheid. Under these conditions, most of his personal experiences contribute to the evolution of protest writing; South African protest literature has also experienced a generation problem. Alex La Guma South African writer, who is 'coloured', written experiences of coloured. Many writers have committed suicide, in desperation, among them, the journalists Can Themba and Nat Nakasa. Other more examples are there, Breyten Bach has been forcibly exiled for his marriage, married with the Vietnamese girl. Alan Paton's passport was seized by the authorities in 1962; and Athol Fugard suffered the same fate after a showing his play The Blood Knot in London in 1967.

The Soweto massacre set off a wave of violence. Throughout the South Africa, apoplectic students soon ablaze down government buildings and beer halls, which led to more confrontations with the police. By the end of 1976, nearly 600 protesters had been killed. Tens of thousands were detained. Many were tortured in jail (McEachernp 71). 'Dispossession 
meant the loss of identity, dignity as well as insecurity and a sense of homelessness. Now separation encompassed their total existence and the private had become overtly political' (McEachernp 79). The origins of the civic movement can be traced indirectly to June 16, 1976. On that day, Soweto student protesters the use of Afrikaans as the medium of instruction in their schools. Two of the protesters were killed by the police. Over the next year, 575 people were killed, and 2,389 were wounded in the general strikes followed the Soweto protest (Tomlinson, et. al. 8). The protest began from the inequality about the human nature and different an educational academic buildings for black and white groups. The numbers of people and students protest for the Apartheid movement. The existence of apartheid effect is influencing even today, deeply rooted in the form of Post-apartheid novels also. To some extent, as a critical attention on Apartheid to Alex La Guma, Mtutuzeli Matshoba, Ahmed Essop, Bessie Head, Nadine Gordimer, and Ronnie Govender, it is interesting to study their writing to make connection of apartheid and post-apartheid period.

\section{CONCLUSION}

To sum up, in 1971 to 1995, this period dealt with apartheid writing in South Africa. AntiApartheid is a part of the reconstruction of the society, which was deconstructed. The protest literature is the process of development and has the aim to create democratic and non-racial society. After the apartheid, yet the marginal people facing the same problems as poverty, weak eco-political status, and health problems. Thus, 'the immediate need for a peaceful environment' and to solve these problems, which are challenging today's world (Morve, 150). The discrimination still is alive issues in the universe and perhaps would never cease in a highly individualistic/materialistic world.

\section{REFERENCES}

Abulencia, A. (2015). Mari Asai's Personal Isolation in Haruki Murakami's After Dark. Asian Journal Of Humanity, Art And Literature, 2(1), 34-38.

Adhikari, Mohamed, ed. Burdened by Race: Coloured Identities in Southern Africa. Cape Town: UCT Press, 2009. Print.

Ashcroft, Bill et. al., eds. The Post-colonial Studies Reader. London: Routledge, 1995. Print.

Ashcroft, Bill, et al. Post-Colonial Studies. Oxon: Routledge, 2000. Print.

Bazin, Nancy Topping, and Marilyn Dallman Seymour, eds. Conversations With Nadine Gordimer. London: University Press of Mississippi, 1990. Print.

Childs, Peter, and R. J. Patric Willaims. An Introduction to Post-colonial Theory. $1^{\text {st }}$ ed. London: Prentice Hall, 1997. Print.

Coetzee, J. M. Giving Offense: Essays on Censorship. Chicago: University of Chicago Press, 1996. Print.

Cruz, D. (2015). Forgotten Memories: Stephanie Ye's Seascrapers. Asian Journal Of Humanity, Art And Literature, 2(1), 29-33.

Eckstein, Lars. English Literatures Across the Globe: A Companion. Paderborn: Fink, 2007. Print.

Fanon, Frantz. Black Skin, White Masks. (1952). Trans. Charles Lam Markmann. London: Pluto Press, 1986. Print.

Glenn, Jordan, and Weedon Chris. Cultural Politics: Class, Gender, Race and the Postmodern World. UK: Blackwell Publishers. 1995. Print.

Gordimer, Nadine. My Son's Story. London: Bloomsbury, 1990. Print.

Graham, Maryemma, and Jerry W. Ward, Jr. The Cambridge History of African American Literature. UK: Cambridge University Press, 2011. Print.

Guillaumin, Colette. Racism, Sexism, Power and Ideology. Oxon: Routledge, 1995. Print.

Herlitzius, Eva-Marie. A Comparative Analysis of the South African and German Reception of Nadine Gordimer's, Andre Brink's and J. M. Coetzee's Works. North America: Transaction Publisher, 2005. Print.

Hughes, Tim. "Ending Apartheid". South African Journal of International Affairs 18.3 (16 November 2011): 437-441. Routledge. Web. Accessed: 18 September, 2013. 07:16. 
Jones, Eldred Durosimi, and Marjorie Jonse, eds. South \& Southern African Literature: A Review. Trenton: Africa World Press, 2002. Print.

Jussawalla, Feroza, and Reed Way Dasenbrock, eds. Interview with Writers of the Post-Colonial World. USA: University Press Mississippi, 1992. Print.

Kam, Rose Sallberg. Alan Paton's Cry, the Beloved Country. United States of America: Barron's Educational Series, Inc., 1985. Print.

Kamali, Masoud. Racial Discrimination: Institutional Patterns and Politics. New York: Roultledge, 2009. Print.

Karmakar, G. (2015). A Theological Study of Nissim Ezekiel's Religious Outlook. Asian Journal Of Humanity, Art And Literature, 2(1), 9-14.

Killam, G. D., and Alicia L. Kerfoo. Student Encyclopedia of African Literature. USA: Greenwood Press, 2008. Print.

McEachernp, Charmaine. Narratives of Nation Media, Memory and Representation in the Making of the New South Africa. Ed. New York: Nova Science Publishers, 2002. Print.

Mehta, Gaurleen, and Harish Narang. Apartheid Fiction. $1^{\text {st }}$ ed. New Delhi: Commonwealth Publishers, 1989. Print.

Mohan, Narendra. "Protest and Literature." Indian Literature, 18. 1 (January-March 1975): 92-95. $\begin{array}{llllll}\text { Sahitya } & \text { Akademi. Web. Accessed: } & 0813 . & \text { June }\end{array}$ <http://www.jstor.org/stable/23333844>.

Morve, Roshan K. "Cultural Identity and Marginal Stratification in "The Storeyed House" by Waman Hoval and Nadine Gordimer's "Country Lovers."" South African Academic Research Journals. Vol. 4.11. (November 2014): 197-202. Web. Accessed: 12 February 2015. 09:14. <http://www.saarj.com/images/download/ACAD,OCT.2011\%20COMPLETE\%20\%20PDF/AC AD.\%20NOVEMBER\%202014\%20ABSTRACT\%20PDF/11.19,\%20Morve\%20Roshan\%20K..pdf >.

Moslund, Sten Pultz. Making Use of History in New South African Fiction. Denmark: Museum Tusculanum Press, 2003. Print.

Mullaney, Julie. Post-Colonial Literatures in Context. New York: Continuum International Publishing Group, 2010. Print.

Nwapa, Flora. Never Again. Enugu, Nigeria: Nwamife Publishers Ltd., 1975. Print.

Obaki, S., Sang, A., \& Ogenga, P. (2013). Lessons from Mahatma Gandhi for Today's School Principals: An Instructional Model. ABC Journal Of Advanced Research, 2(2), 44-54.

Olubunmi, A., \& Tar, M. (2015). Impact of Psychological Well-Being on the Vocabulary Acquisition Level of Nigerian Adolescents Learning French Language in Rural Settings. Asian Journal Of Humanity, Art And Literature, 2(1), 24-28.

Roshan K., M. (2014). Contextualizing Power Politics of Tamasha Art and Female Suffering in Dalit Autobiography.Asian Journal Of Humanity, Art And Literature, 1(2), 77-83.

Roshan K., M. (2014). Representation of History in Chimamanda Ngozi Adichie's Half of a Yellow Sun (2006). Asian Journal Of Humanity, Art And Literature, 1(3), 150-154.

Sadeghi, B., \& Safari, R. (2012). The Impact of Collaborative Task on the FL Vocabulary Acquisition. ABC Journal Of Advanced Research, 1(2), 8-14.

Saint, Lily. "Reading Subjects: Passbooks, Literature and Apartheid." Social Dynamics: A Journal of African Studies. (2 Aug. 2012): 117-133. 38. 1 Routledge. Web. Accessed: 29 July 2013. 01:56. <http://www.tandfonline.com/doi/pdf/10.1080/02533952.2012.700178>.

Saro-Wiwa, Ken. Sozaboy. London: Longman African Writers.1994. Print.

Shapiro, Ian, and Kahreen Tebeau, eds. After Apartheid: Reinventing South Africa?. Charlottesville: University of Virginia Press, 2011. Print.

Sidi-Said, F. (2014). Domesticity as Gender Othering in Joseph Conrad's The Secret Agent. Asian Journal Of Humanity, Art And Literature, 1(1), 41-47.

Smyer, Richard I. "Africa in the Fiction of Nadine Gordimer." ARIEL: A Review of International English Literature. (April 1985): 15-29. Vol. 16.2 University of Calgary Press. Web. Accessed: 1 July 2013. 11:26. <http://ariel.synergiesprairies.ca/ariel/index.php/ariel/article/view/1885/1842>.

Sonneborn, Liz. The End of Apartheid in South Africa. New York: Infobase Publishing Press, 2010. Print. Talib, Ismail S. The Language of Postcolonial Literatures: An Introduction. New York: Roultledge, 2002. Print.

Yousaf, Nahem, ed. Apartheid Narratives. New York: Amsterdm, 2001. Print. 